\title{
DAMPAK PENCABUTAN SUBSIDI BBM BAGI KEUANGAN NEGARA INDONESIA DALAM PERSPEKTIF GOOD GOVERNANCE
}

\author{
Julian Muhammad Hasan \\ Universitas Pamulang \\ email: julianmuhammadhasan@gmail.com
}

Paper Accepted: 14 Maret 2018 Paper Reviewed: 20-27 Maret 2018 Paper Edited: 01-15 April 2018 Paper Approved: 20 April 2018

\begin{abstract}
In the discussion of this research is about the consistent implementation of fuel subsidies that resulted in the government must provide regular budget for domestic fuel sales such as kerosene, gasoline, avgas, avatur, and other types of fuel at low prices. With this policy, fuel subsidy by itself has an effect on the increase of fuel demand which at the same time increase domestic electricity usage. With the consistency of the fuel subsidy, both society and companies are allowed to purchase cheap domestic fuel prices by ignoring the scarcity factor of their natural resources. In 2014, the Indonesian government has revoked fuel subsidies. It has also passed the stage of consideration and has studied the policy plan to divert fuel subsidies from consumptive to productive. The policy will also have a positive impact and the negative impact of the revocation of subsidies. But with the way the policy is the most important is not out of the path of the concept of "Good Governance" whichrequired commitment and involve all parties namely the government and the community in applying the concept.
\end{abstract}

Keywords: State Finance, Good Governance, Fuel Subsidy

\section{PENDAHULUAN}

\section{Latar Belakang Masalah}

Dalam era globalisasi yang saat ini sedang berkembang pesat di suatu negara, terutama dalam hal mensejahterkan masyarakat masih menjadi polemik bagi bangsa dan negara. Hal ini berkaitan dengan fungsi dan tugas utama pemerintah secara umum, yaitu memberi pelayanan kepada masyarakat.

Dengan pemberian pelayanan yang baik kepada masyarakat maka pemerintah akan dapat mewujudkan tujuan Negara yaitu menciptakan kesejahteraan masyarakat. Pelayanan kepada masyarakat tersebut terintegrasi dalam penyelenggaraan pemerintahan dan pembangunan. Di Indonesia untuk melakukan pelayanan publik dalam rangka menciptakan kesejahteraan rakyat salah satunya adalah melalui pelaksanaan subsidi BBM (Bahan Bakar Minyak).

Pada masa Orde Baru, pemberlakuan subsidi BBM secara konsisten mengakibatkan pemerintah harus menyediakan anggaran rutin untuk penjualan BBM di dalam negeri seperti minyak tanah, bensin, avgas, avatur, dan jenis BBM lainnya dengan harga murah. Dengan kebijakan ini, subsidi BBM dengan sendirinya berefek pada peningkatan permintaan BBM yang sekaligus meningkatkan penggunaan energi listrik di dalam negeri. Dengan konsistensi subsidi BBM ini, baik masyarakat maupun perusahaan dininabobokan oleh pembelian harga BBM yang murah di dalam negeri dengan mengabaikan faktor kelangkaan sumber-sumber alamnya. Sekali lagi, hal ini justru mendorong peningkatan konsumsi BBM dalam negeri karena masyarakat sudah terlanjur disuapi BBM domestik yang murah dan pemerintah pun tampaknya semakin tidak realistis terhadap perkembangan harga BBM internasional yang cenderung meningkat.

Di tahun 2014 ini pemerintah Indonesia telah mencabut subsidi BBM sebesar Rp.2.000 yang harga jualnya ditetapkan dari Rp.6.500 menjadi Rp.8.500 dan harga solar yang ditetapkan dari Rp.5.500 menjadi Rp7.500. Presiden Jokowi menjelaskan, bahwa jajarannya 
telah mendalami rencana kebijakan untuk mengalihkan subsidi BBM dari konsumtif menjadi produktif. Ia bahkan menerangkan kebijakan itu sudah dibahas di rapat terbatas di Istana hingga tingkatan teknis di kementerian. Presiden Jokowi mengingatkan, negara membutuhkan anggaran untuk membiayai infrastruktur, pendidikan, dan kesehatan. Jokowi pun menjelaskan bahwa anggaran tersebut tidak tersedia karena dihamburkan untuk subsidi BBM.

Atas terjadinya pencabutan subsidi BBM tersebut, banyak terjadinya pro dan kontra dari kalangan masyarakat maupun para elit politik. Salah satu alasan yang menolak atas pencabutan subsidi BBM adalah kekhawatiran adanya lonjakan harga barang dan jasa serta akan terjadi peningkatan angka kemiskinan.

Selain itu, menurut Herman Khaeron (Ketua DPP Partai Demokrat) pemerintahan Jokowi-JK mengabaikan prinsip Good Governance atau tata kelola pemerintahan yang baik tanpa terlebih dahulu berkonsultasi dengan DPR atas kebijakan pencabutan subsidi BBM meskipun hal tersebut merupakan hak prerogatif Presiden, namun mekanisme yang ditempuh kurang transparan dan akuntabel.

\section{Perumusan Masalah}

Penulis membatasi rumusan masalah dengan mengajukan beberapa pertanyaan agar tidak melebar dari konteks permasalahan tersebut, diantaranya, yaitu :

1. Apa saja dampak-dampak atas pencabutan subsidi BBM terhadap keuangan Negara di Indonesia?

2. Apakah implementasi pencabutan subsidi BBM sudah sesuai dengan konsep Good Governance di Indonesia?

\section{Tujuan Penulisan}

Tujuan dari penulisan ini adalah :

1. Untuk mengetahui dampak-dampak pencabutan subsidi BBM di Indonesia.

2. Untuk mengetahui permasalahan yang akan muncul berkaitan dengan pencabutan subsidi BBM dalam perspektif Good Governance.

\section{Manfaat Penulisan}

Manfaat dari penulisan ini adalah :

1. Hasil penulisan ini semoga dapat memberi manfaat kepada semua pihak, khususnya kepada yang membacanya agar bisa menambah wawasan dan pengetahuan mengenai "Dampak Pencabutan Subsidi BBM Bagi Keuangan Negara Indonesia Dalam Perspektif Good Governance".

2. Semoga bisa dijadikan acuan dalam menganalisis kebijakan pemerintah yang akan merumuskan masalah atas dampak pencabutan subsidi BBM.

\section{KAJIAN PUSTAKA}

\section{Subsidi}

Subsidi adalah pembayaran yang dilakukan pemerintah kepada perusahaan atau rumah tangga untuk mencapai tujuan tertentu yang membuat mereka dapat memproduksi atau mengkonsumsi suatu produk dalam kuantitas yang lebih besar atau pada harga yang lebih murah.

Secara ekonomi tujuan subsidi adalah mengurangi harga atau menambah keluaran (output). Arti kata subsidi menurut Kamus Besar Bahasa Indonesia adalah bantuan uang dan sebagainya kepada yayasan, perkumpulan, dan sebagainya (biasanya dari pihak pemerintah) (Makmun, 2008).

Selanjutnya, menurut Suparmoko yang sebagaimana dikutip oleh Dungtji Munawar (2013), subsidi (transfer) adalah salah satu bentuk pengeluaran pemerintah yang juga diartikan sebagai pajak negatif yang akan menambah pendapatan mereka yang menerima subsidi atau mengalami peningkatan pendapatan riil apabila mereka mengkonsumsi atau membeli barang-barang yang disubsidi oleh pemerintah dengan harga jual yang rendah. Subsidi dapat dibedakan dalam dua bentuk yaitu subsidi dalam bentuk uang (cash transfer) dan subsidi dalam bentuk barang atau subsidi innatura (in kind subsidy).

Dengan demikian, subsidi merupakan upaya pemerintah melalui penyaluran anggaran kepada produsen barang dan jasa dalam rangka pelayanan publik sehingga masyarakat dapat memenuhi hajat hidupnya dengan harga beli yang lebih terjangkau atas barang dan jasa publik yang disubsidi tersebut.Jadi bisa disimpulkan bahwa subsidi adalah bantuan pemerintah dalam bentuk bantuan keuangan yang dibayarkan kepada produsen dan konsumen suatu bisnis atau sektor ekonomi atas barang/jasa tertentu.

\section{Good Governance}

Istilah "Good Governance” mulai muncul dan popular di Indonesia sekitar tahun 1990an. Dalam penyelenggaraan pemerintahan "Good Governance" menjadi sangat penting dan 
strategi mengingat kemunculannya di saat penyelenggaraan pemerintahan Indonesia sedang mengalami distorsi terhadap efektivitas pelayanan kepada publik, dalam arti bahwa sudah menjadi bukan rahasia umum apabila berurusan dengan birokrasi pemerintah yang dialami yaitu berbelit-belit sangat lamban, penuh dengan pungutan liar, pelayanan yang kurang baik dan lain-lain. Oleh karena itu "Good Governance" seperti obat mujarab untuk mengobati penyakit birokrasi pemerintah tersebut.

Pengertian 'Good Governance” itu sendiri menurut UNDP (United Nations Development Programme) adalah proses penyelenggaraan kekuasaan negara dalam melaksanakan penyediaan public goods and service disebut governance (pemerintah atau kepemerintahan), sedangkan praktek terbaiknya disebut "Good Governance" (kepemerintahan yang baik). Agar "Good Governance" dapat menjadi kenyataan dan berjalan dengan baik, maka dibutuhkan komitmen dan keterlibatan semua pihak yaitu pemerintah dan masyarakat. "Good Governance" yang efektif menuntut adanya "aligment" (koordinasi) yang baik dan integritas, profesional serta etos kerja dan moral yang tinggi. Dengan demikian penerapan konsep "Good Governance" dalam penyelenggaraan kekuasaan pemerintah negara merupakan tantangan tersendiri.

Sedangkan prinsip-prinsip Good Governance versi UNDP yaitu saling memperkuat dan tidak dapat berdiri sendiri. Adapun uraian dibawah ini yang terkait dengan "prinsip good governance" adalah sebagai berikut :

a. Participation; setiap warga negara mempunyai suara dalam pembuatan keputusan, baik secara langsung maupun melalui intermediasi Institusi legitimasi yang mewakili kepentingannya. Partisipasi ini dibangun atas dasar kebebasan berasosiasi dan berbicara serta berpartisipasi secara konstruktif.

b. Rule of Law; kerangka hukum harus adil dan dilaksanakan tanpa perbedaan, terutama hukum hak azasi manusia.

c. Transparancy; transparasi dibangun atas dasar kebebasan arus informasi. Proses lembaga dan informal secara langsung dapat diterima oleh mereka yang membutuhkan informasi dapat dipahami dan dapat dipantau.

d. Responsiveness; lembaga dan proses harus mencoba untuk melayani setiap stakeholder. e. Consensus Orientation; "Good Governance" menjadi perantara kepentingan yang berbeda untuk memperoleh pilihan terbaik bagi kepentingan yang lebih luas, baik dalam hal kebijakan maupun prosedur.

f. Effectiveness and Efficiency; proses dan lembaga menghasilkan sesuai dengan apa yang telah digariskan dengan menggunakan sumber yang tersedia sebaik mungkin.

g. Accountability; para pembuat keputusan dalam pemerintahan sektor swasta dan masyarakat (civil society) bertanggung jawab kepada pihak publik dan lembaga stakeholder.

h. Strategy Vision; para pemimpin dan publik harus mempunyai perspektif "Good Governance"dan pengembangan manusia yang luas serta jauh ke depan sejalan dengan apa yang diperlukan untuk pembangunan semacam ini.(Istianto, 2011)

\section{METODOLOGI}

\section{Jenis dan Sumber Data}

Penelitian ini akan menggunakan data sekunder. Melalui studi kepustakaan yang diharapkan dapat mempelajari "Dampak Pencabutan Subsidi BBM Bagi Keuangan Negara Indonesia Dalam Perspektif Good Governance" secara teoritis maupun empiris. Sumber-sumber data ini berupa buku, jurnal, internet, hasil penelitian dan penerbitanpenerbitan lainnya.

\section{Metode Penelitian}

Jenis penelitian ini menggunakan metode kualitatif yang bertumpu pada beberapa aliran, tradisi, atau teori yang kesemuanya menekankan pada pentingya pengembangan penyusunan teori yang ditandai dengan strategi induktif empiris (Suyanto dan Sutinah 2007). Sebagai contoh kualitatif adalah penelitian yang dikonseptualisasikan sebagai studi kasus dan berfokus pada interpretasi, hal ini yang melibatkan data kualitatif. Atau, sebagai contoh metode campuran, mungkin sebuah survei kuantitatif yang akan diikuti dengan data kualitatif. (Punch, 2000)

\section{HASIL DAN PEMBAHASAN}

\section{Isu Pencabutan Subsidi BBM}

Subsidi BBM diatur dalam UU No 12/2014 tentang APBN-P 2014. Pasal 14 ayat 13 menyebutkan "Anggaran untuk subsidi energi yang merupakan bagian dari program 
pengelolaan subsidi sebagaimana dimaksud pada ayat (1) dapat disesuaikan dengan kebutuhan realisasi harga minyak mentah (ICP) dan nilai tukar rupiah." Adapun ayat 1 berisi "Program subsidi dalam tahun anggaran 2014 diperkirakan sebesar Rp403.035.574.566.000 (empat ratus tiga triliun tiga puluh lima miliar lima ratus tujuh puluh empat juta lima ratus enam puluh enam ribu rupiah)."(Prabowo, 2014) Anggaran tersebut, pada masa pemerintahan Jokowi-JK telah mengambil kebijakan pencabutan anggaran subsidi BBM bahwa alasannya menaikkan harga Bahan Bakar Minyak (BBM) bersubsidi yaitu untuk mengalihkan segi konsumtif ke segi produktif.

Bahkan Presiden Jokowi juga meminta kepada masyarakat bahwa proses peralihan di sektor konsumtif ke sektor produktif memerlukan waktu yang sangat panjang dan tidak langsung kelihatan, diperkirakan tahun depan akan terlihat realisasinya. Presiden Jokowi pun mengatakan bahwa kenaikan harga BBM bersubsidi adalah dalam rangka mengoptimalkan Anggaran Pendapatan dan Belanja Negara (APBN). (Manafe, 2014).

Di Indonesia pengelolaan BBM dimotori oleh PT Pertamina (Persero) sebagai Perusahaan BUMN sejak tahun 1957 hingga berubah status hukum menjadi Perusahaan Perseroan Terbatas (Persero).Pertamina merupakan perusahaan milik negara yang bergerak di bidang energi meliputi minyak, gas serta energi baru dan terbarukan. Pertamina menjalankan kegiatan bisnisnya berdasarkan prinsip-prinsip tata kelola korporasi yang baik sehingga dapat berdaya saing yang tinggi di dalam era globalisasi. (Pertamina.com)

Menurut Andrinof Chaniago (Menteri Perencanaan Pembangunan Negara/Kepala Bappenas) dengan penghematan subsidi BBM, pemerintah akan meningkatkan produksi pangan dan akan mencapai swasembada pangan dalam dua tahun serta pengalihan subsidi juga akan digunakan untuk meningkatkan produksi energi, mempercepat pembangunan pembangkit listrik, sektor maritim, dan pembangunan jalan.

Sebagaimana yang kita ketahui bahwa harga jual BBM yang telah ditetapkan setelah dicabutnya subsidi BBM, yaitu sebesar Rp6.500 menjadi Rp8.500 untuk premium dan harga solar yang ditetapkan dari Rp5.500 menjadi Rp7.500. (Saputri, 2014)

Terkait dengan hal tersebut, pemerintah akan menyiapkan skema penyaluran dana kompensasi kenaikan harga bahan bakar minyak (BBM) bersubsidi dengan menggunakan uang elektronik. Menurut Bambang Brodjonegoro (Menteri Keuangan) kompensasi yang akan diberikan kali ini agak berbeda dengan Bantuan Langsung Tunai (BLT) dan Bantuan Langsung Sementara (BLSM) karena pemerintah tidak sekadar memberikan uang tunai, namun memberi bantuan secara spesifik untuk kesejahteraan masyarakat. Ia pun mengatakan bahwa bantuan tersebut diwujudkan melalui pembagian Kartu Indonesia Sehat (KIS), Kartu Indonesia Pintar (KIP), dan Kartu Keluarga Sejahtera (KKS). Penyaluran dana kompensasi kenaikan harga BBM bersubsidi melalui kartukartu tersebut adalah wujud upaya penerapan visi Presiden Joko Widodo.

Ketiga program itu akan menjadi skema tetap penyaluran bantuan dari pemerintah bukan yang sifatnya ad hoc (sementara). Bambang yakin cara ini akan efektif karena memiliki sistem yang jelas. Nantinya, kartu-kartu ini diberikan kepada satu keluarga. Kartu Keluarga Sejahtera berfungsi menjaga daya beli masyarakat. Kartu Indonesia Sehat digunakan untuk pembiayaan kesehatan baik di puskesmas maupun rumah sakit. Dan anak-anak di dalam keluarga akan menerima Kartu Indonesia Pintar sebagai bentuk penyaluran bantuan pendidikan. (Nawangwulan, 2014) Dengan demikian, kekhawatiran masyarakat atas kenaikan harga BBM akan diberikan kompensasi oleh pemerintah dengan kartu-kartu tersebut yang tentunya harus dimanfaatkan dengan baik oleh masyarakat.

Disamping itu, kenaikan harga BBM dinilai belum tentu meningkatkan angka kriminal jalanan. Kenaikan harga BBM justru membuat para mafia migas terusik kepentingannya. Menurut Muhammad Mustofa (Kriminolog Universitas Indonesia) Kenaikan harga BBM yang paling terkena dampaknya adalah mafia migas. Selama ini, mafia migas merasa berada di zona nyaman untuk beraksi dan mafia migas justru senang sekali melihat mahasiswa demo atau yang kontra terhadap kenaikan harga BBM bersubsidi.

Di saat mahasiswa unjuk rasa mereka tertawa seolah kepentingannya dibela, menjadi kontra produktif yang hanya diperalat saja oleh para mafia migas. Sementara untuk angka kejahatan konvensional, Mustofa justru tak khawatir akan terjadi peningkatan meski peluangnya tetap ada. Dia pun mengatakan, aparat keamanan pasti meningkatkan kewaspadaan atas kebijakan kenaikan harga BBM. Faktor ekonomi, tak selalu berkaitan dengan angka kriminal. (Virdhani, 2014) Oleh karena itu, berarti selama ini subsidi BBM dinikmati oleh para mafia migas dan hal ini mengakibatkan kerugian keuangan Negara serta mengalami defisit. 
Menurut Abdul Kadir Karding (Sekjen PKB) menyatakan bahwa, tidak ada cara lain untuk menyelamatkan keuangan negara selain menaikkan harga BBM bersubsidi. Dia pun menegaskan bahwa, tidak ada pilihan bagi Presiden kecuali mengalihkan subsidi karena pemerintah siapapun pasti akan terpaksa melakukan hal ini. Dia menilai, subsidi harus dialihkan karena tiga tahun negara mengalami defisit anggaran. Biaya belanja negara selama ini dibiayai oleh utang ke luar negeri dan defisit Negara mencapai Rp106 triliun. (Firdaus, 2014) Selain itu, pemerintahan Jokowi-JK dalam memberantas mafia migas dan programprogram pengalihan subsidi BBM harus transparan dan akuntabel serta harus menerapkan prinsip-prinsip Good Governance.

Terkait dengan prinsip Good Governance, Herman Khaeron (Ketua DPP Partai Demokrat) mengatakan bahwa pemerintahan Jokowi-JK telah mengabaikan prinsip Good Governance atau tata kelola pemerintahan yang baik tanpa terlebih dahulu berkonsultasi dengan DPR atas kebijakan pencabutan subsidi BBM, meskipun hal tersebut merupakan hak prerogatif Presiden, namun mekanisme yang ditempuh kurang transparan dan akuntabel. Bahkan pembagian Kartu Indonesia Sehat (KIS), Kartu Indonesia Pintar (KIP), dan Kartu Keluarga Sejahtera (KKS) tidak berkonsultasi dengan DPR dan penjelasan kepada publik. Ia menilai, Presiden Jokowi terkesan terburu-buru dan mengabaikan berbagai dampak yang ditimbulkannya, yaitu sudah dapat dipastikan seluruh harga akan naik dan dipastikan juga akan menurunkan daya beli masyarakat.

Selain itu, diperlukan persiapan yang matang untuk menaikkan harga BBM bersubsidi berikut dengan program perlindungan sosial dan kompensasinya sehingga harus ada penjelasan yang utuh sesuai dengan perundang-undangan agar ke depan tidak menimbulkan permasalahan serta arah penggunaan penghematannya, bisa diputuskan secara legitimasi. (Gatra, 2014)

Pada akhirnya Pratikno (Menteri Sekretaris Negara) menjawab kritikan yang dilontarkan oleh para politisi maupun masyarakat atas biaya penerbitan Kartu Indonesia Sehat (KIS), Kartu Indonesia Pintar (KIP), dan Kartu Keluarga Sejahtera (KKS). Penerbitan semua kartu yaitu anggarannya berasal dari Corporate Social Responsibility (CSR) BUMN yang sifatnya hanya sementara, namun untuk tahun berikutnya, pengadaan KIS, KIP, dan KKS akan dimasukkan ke dalam Anggaran Pendapatan dan Belanja Negara (APBN). Pratikno mengungkapkan bahwa para anggota DPR jangan terlalu terburu-buru untuk menghakimi anggaran penerbitan kartu tersebut. Bahkan, yang terpenting adalah fokus pada kelancaran penyelenggaran program KIS, KIP, dan KKS. Selama ini banyak anggaran yang tersedia, tapi tidak fokus, maka untuk saat ini pemerintah akan fokus terhadap program-program yang pro-rakyat. (Asril, 2014)

Jusuf Kalla (Wakil Presiden) pun menegaskan bahwa program Kartu Indonesia Sehat, Kartu Keluarga Sejahtera, dan Kartu Indonesia Pintar memiliki payung hukum. Begitu pun dengan anggarannya, ada di Anggaran Pendapatan dan Belanja Negara (APBN). Sedangkan payung hukum Kartu Indonesia Pintar ada di bawah Kementerian Kebudayaan, Pendidikan Dasar dan Menengah. Sedangkan Kartu Keluarga Sejahtera di bawah Kementerian Sosial. Jusuf Kalla pun menyebutkan bahwa payung hukum tersebut ada di Pasal 1 ayat (3) UUD 1945, maka konsekuensinya seluruh tindakan pemerintah wajib tunduk pada peraturan perundangundangan yang berlaku, termasuk tindakan menerbitkan KIS, KIP dan KKS, itu yang harus memiliki dasar hukum. (Aspasia, 2014)

\section{Dampak Pencabutan Subsidi BBM}

Setiap ada rencana pemerintah dalam mengurangi subsidi harga BBM, pasti selalu ada pro dan kontra di kalangan masyarakat maupun elit politik. Sebagian masyarakat merasa perlu tetap ada subsidi untuk membantu masyarakat miskin. Namun sebagian lainnya percaya, dana subsidi harusnya dialihkan ke sektor produktif yang tujuan akhirnya juga untuk meningkatkan kesejahteraan masyarakat. Katadata berpendapat bahwa Pemerintah perlu segera menyusun rencana (roadmap) yang jelas untuk mengurangi subsidi BBM secara bertahap guna mengakhiri era BBM murah.

Pemerintah sebaiknya kembali menerapkan kebijakan subsidi tetap harga BBM seiring fluktuasi harga minyak dunia, seperti pernah diterapkan oleh pemerintahan Abdurrahman Wahid dan Megawati Soekarnoputri. Berikut ini ada 10 alasan menurut Katadata mengapa harga BBM saat ini harus naik : Pertama; Indonesia negara boros subsidi, Kedua; neraca defisit dan rupiah terpukul, Ketiga; 53\% subsidi dinikmati mobil pribadi, Keempat; Indonesia bukan kaya minyak, Kelima; Indonesia bukan lagi eksportir minyak, Keenam; rezim subsidi BBM kian ditinggalkan, Ketujuh; Negara petrodolar pun siap pangkas subsidi, Kedelapan; dana migas tekor untuk subsidi energi, Kesembilan; ketimpangan subsidi energi, Kesepuluh; menghambat tumbuhnya energi alternatif. (Katadata, 2014) 
Adapun dampak kenaikan harga BBM yang dapat menimbulkan dampak positif dan dampak negatif di Negara Indonesia, yaitu : dampak positifnya adalah

1) masyarakat akan beralih ke BBM nonsubsidi (pertamax),

2) masyakarat akan beralih ke transportasi publik,

3) berkurangnya pencemaran udara,

4) pembangunan infrastruktur, pendidikan dan kesehatan.

Dampak negatifnya adalah

1) meningkatnya jumlah pengangguran yang menyebabkan meningkatnya angka kemiskinan,

2) naiknya harga barang dan jasa,

3) terjadinya inflasi terhadap perekonomian Indonesia. Hal ini merupakan kebijakan pemerintahan Jokowi-JK yang beresiko tinggi dalam mengambil sebuah tindakan dan masyarakat harus siap dalam menerima kenaikan BBM tersebut.

Namun disamping terjadinya kenaikan BBM di Indonesia, ternyata harga minyak dunia merosot ke titik terendah setelah negara produsen minyak yang tergabung dalam OPEC (Organization of Petroleum Exporting Countries) memutuskan tidak menurunkan produksi di tengah pasar yang kelebihan pasokan. Artinya harga minyak dunia turun tapi harga BBM di Indonesia malah naik, oleh karena itu Sudirman Said (Menteri Energi dan Sumber Daya Mineral) mengatakan pemerintah akan terus memantau pergerakan harga minyak dunia yang terus melemah, jika harga turun terus, artinya harga keekonomian juga akan turun. Serta pemerintah akan menjaga disparitas harga BBM bersubsidi dengan nonsubsidi setipis mungkin.

Dengan demikian, penyelundupan dan penyelewengan BBM bersubsidi bisa diatasi. Kondisi ini memungkinkan harga BBM bersubsidi harus terus didorong mendekati harga pasar. Di sisi anggaran, beban subsidi yang kecil memberikan ruang bagi pemerintah untuk membangun infrastruktur. (Firmansyah dan Munthe, 2014)

\section{Inflasi Pada Perekonomian Negara dan Solusinya}

Rencana pemerintah menaikkan harga BBM bersubsidi di akhir tahun, bersamaan dengan periode inflasi yang tinggi. Karena itu, lonjakan inflasi pasca kenaikan BBM pun akan sulit dibendung. Menurut Suryamin (Kepala Badan Pusat Statistik) mengatakan, berdasarkan simulasi, kenaikan BBM akan memicu kenaikan inflasi langsung sebesar 1,7 persen pada bulan pertama. Jika kenaikan harga BBM dilakukan pada pertengahan November, maka tambahan inflasi langsung 1,7 persen akan terbagi dua pada November dan Desember. Tapi, apabila kenaikan dilakukan awal Desember, maka dampak inflasi 1,7 persen akan berlangsung pada akhir tahun. (JPNN, 2014)

Namun, Badan Pusat Statistik (BPS) mencatat inflasi bulan November 2014 sebesar 1,5 persen atau naik dibanding bulan Oktober sebesar 0,47 persen. Inflasi itu dipengaruhi kenaikan harga BBM di bulan November. Kendati inflasi mengalami kenaikan, tapi dampak kenaikan BBM November lalu tak sebesar kenaikan BBM pada Juni 2013 yang mencapai hingga 3,2 persen.

Salah satu hal yang terpenting dalam menaikan harga BBM adalah pemilihan waktu, kebijakan pemerintah untuk menaikkan harga BBM merupakan waktu yang tepat karena tren inflasi November sangat rendah. Menurut data BPS, jika menilik angka inflasi November ratarata di bawah 0,5 persen. Pada November 2009 mengalami deflasi 0,03 persen. Pada November 2010 inflasi sebesar 0,6 persen. Inflasi bulan yang sama 2011 dan 2012 tercatat 0,34 persen dan 0,07 persen. Sedangkan tahun lalu inflasi November 0,12 persen.

Angka inflasi bulan November ini sejalan dengan prediksi Bank Indonesia yang menghitung inflasi hingga minggu ketiga November sebesar 1,4 persen. Gubernur BI Agus Martowardojo mengatakan naiknya inflasi dipengaruhi kenaikan harga BBM dan gejolak harga pangan. (Kamaludin, 2014) Namun, Pemerintah optimistis inflasi akan kembali menciut pada Desember 2014, bahkan diproyeksikan deflasi di awal tahun depan. Menurut Sofyan Djalil (Menko Perekonomian) mengatakan andil dari naiknya ongkos angkutan transportasi yang pada gilirannya menyebabkan kenaikan harga pangan sudah diantisipasi pemerintah.

Untuk angkutan perkotaan dan angkutan pedesaan, kenaikan tarif disesuaikan dengan kondisi dan daya beli masyarakat setempat. Artinya, penyesuaian tarif menjadi wewenang pemerintah daerah dan kota masing-masing. Namun demikian, Kementerian Dalam Negeri dipastikan akan turut mengontrol kenaikan tarif angkutan di setiap daerah. Selain itu, upaya pengendalian kenaikan tarif angkutan bukan hanya menyasar langsung pada orang, tapi juga distribusi barang. Oleh karena itu, sejalan dengan kenaikan harga BBM, pemerintah akan tetap menjaga efektivitas logistik di pelabuhan, 
khususnya untuk barang-barang yang menjadi kebutuhan pokok seperti cabai dan bawang. (Wicaksono, 2014)

Disamping itu, Presiden Joko Widodo memberikan strategi pemerintah untuk menekan inflasi pasca kenaikan harga BBM. Menurut Jokowi, salah satu cara taktis adalah memastikan distribusi barang terutama kebutuhan pokok agar tak terhambat dan harus selalu pantau di lapangan yang biasanya disebut dengan blusukan.

Selain itu, pemerintah juga akan terus mengawasi ketersediaan barang di pasar. Sehingga, masyarakat tidak sulit mencari bahan kebutuhan pokok sehingga harganya dijual mahal oleh pedagang. Misalnya seperti stok barang yang ada di grosir dan distributor yang akan terus dicek dan dipantau agar inflasi yang ditargetkan tidak lebih dari 2 persen.

Sebelumnya, Bank Indonesia (BI) justru menyebut kunci besaran inflasi setelah kenaikan harga (BBM) bersubsidi berasal dari tarif angkutan umum. Sebab, menurut BI, berdasarkan pengalaman kenaikan BBM bersubsidi sebelumnya, komponen penyumbang inflasi tertinggi adalah kenaikan tarif angkutan umum. BI meyakini, kenaikan harga BBM bersubsidi tidak akan terlalu berdampak negatif pada laju inflasi. Namun, BI akan menyiapkan sejumlah kebijakan strategis agar dampak kenaikan BBM tetap terkendali. Langkah strategis yang akan ditempuh adalah bekerjasama dengan Pemerintah Pusat dan Pemerintah Daerah untuk memperkuat koordinasi pengendalian inflasi. (Globalindo, 2014).

Dengan demikian, bahwa strategi dan solusi yang diberikan oleh Jokowi adalah dengan melakukan monitoring atau pengawasan yang biasa dikenal dengan sebutan blusukan, untuk memastikan distribusi barang terutama kebutuhan pokok agar tak terhambat dan tidak ada lagi penjual "nakal" yang secara sengaja menaikan harga barang yang dapat menimbulkan inflasi yang tinggi, serta kerjasama antara Pemerintah Pusat dan Pemerintah Daerah harus saling terkoordinasi dalam pengurangan inflasi.

\section{PENUTUP}

\section{Kesimpulan}

Kenaikan harga BBM bersubsidi adalah dalam rangka mengoptimalkan Anggaran Pendapatan dan Belanja Negara (APBN) serta mengalihkan subsidi BBM dari konsumtif menjadi produktif. Atas kenaikan harga tersebut, pemerintah akan menyiapkan skema penyaluran dana kompensasi dengan menggunakan uang elektronik. Bantuan tersebut diwujudkan melalui pembagian Kartu Indonesia Sehat (KIS), Kartu Indonesia Pintar (KIP), dan Kartu Keluarga Sejahtera (KKS). Penyaluran dana kompensasi tersebut adalah wujud upaya penerapan visi Presiden Joko Widodo. Namun, bantuan KIS, KIP dan KKS masih dipertanyakan darimana asal anggaran tersebut. Implementasinya pun tidak berkonsultasi dengan DPR dan tidak memberikan penjelasan kepada publik darimana asal dana kartu-kartu tersebut. Hal itu mengabaikan prinsip Good Governance atau tata kelola pemerintahan yang baik, meskipun hal tersebut merupakan hak prerogatif Presiden, namun mekanisme yang ditempuh kurang transparan dan akuntabel.

Pada akhirnya Pratikno (Menteri Sekretaris Negara) menjawab kritikan atas biaya penerbitan KIS, KIP dan KKS. Penerbitan semua kartu tersebut anggarannya berasal dari Corporate Social Responsibility (CSR) BUMN yang sifatnya hanya sementara, namun untuk tahun berikutnya, pengadaan KIS, KIP, dan KKS akan dimasukkan ke dalam APBN. Bahkan, Pratikno menganjurkan bahwa yang terpenting sekarang ini adalah fokus pada kelancaran penyelenggaran program KIS, KIP, dan KKS. Selanjutnya, Jusuf Kalla (Wakil Presiden) pun menegaskan bahwa program KIS, KIP, dan KKS memiliki payung hukum. Begitu pun dengan anggarannya, ada di APBN dan payung hukumnya ada di Pasal 1 ayat (3) UUD 1945.

Adapun dampak kenaikan harga BBM yang dapat menimbulkan dampak positif dan dampak negatif di Negara Indonesia, yaitu : dampak positifnya adalah Pertama; masyarakat akan beralih ke BBM non-subsidi (pertamax), Kedua; masyakarat akan beralih ke transportasi publik, Ketiga; berkurangnya pencemaran udara, Keempat; pembangunan infrastruktur, pendidikan dan kesehatan. Dampak negatifnya adalah Pertama; meningkatnya jumlah pengangguran yang menyebabkan meningkatnya angka kemiskinan, Kedua; naiknya harga barang dan jasa, Ketiga; terjadinya inflasi terhadap perekonomian Indonesia. Hal ini merupakan kebijakan pemerintahan Jokowi-JK yang beresiko tinggi dalam mengambil sebuah tindakan dan masyarakat harus siap dalam menerima kenaikan BBM tersebut.

Terkait dengan inflasi, pada awalnya Badan Pusat Statistik (BPS) memprediksi bahwa kenaikan inflasi atas kenaikan BBM sebesar 1,7persen pada bulan November 2014. 
Namun prediksi BPS meleset, ternyata inflasi di bulan November 2014 hanya sebesar 1,5 persen atau naik dibanding bulan Oktober sebesar 0,47 persen dan bila dibandingkan dengan dampak kenaikan BBM pada Juni 2013 yaitu mencapai 3,2 persen. Salah satu hal yang terpenting dalam menaikan harga BBM adalah ketepatan waktu, karena tren inflasi November sangat rendah. Disamping itu, Presiden Joko Widodo memberikan strategi pemerintah untuk menekan inflasi pasca kenaikan harga BBM. Salah satu cara taktisnya adalah memastikan distribusi barang terutama kebutuhan pokok agar tak terhambat dan harus selalu pantau di lapangan.

Selain itu, pemerintah juga akan terus mengawasi ketersediaan barang di pasar. Sehingga, masyarakat tidak sulit mencari bahan kebutuhan pokok sehingga harganya dijual mahal oleh pedagang. Misalnya seperti stok barang yang ada di grosir dan distributor yang akan terus dicek dan dipantau agar inflasi yang ditargetkan tidak lebih dari 2 persen. Dengan demikian, bahwa strategi dan solusi yang diberikan oleh Jokowi adalah dengan melakukan monitoring atau pengawasan yang biasa dikenal dengan sebutan blusukan, untuk memastikan distribusi barang terutama kebutuhan pokok agar tak terhambat dan tidak ada lagi penjual "nakal" yang secara sengaja menaikan harga barang yang dapat menimbulkan inflasi yang tinggi, serta kerjasama antara Pemerintah Pusat dan Pemerintah Daerah harus saling terkoordinasi dalam pengurangan inflasi.

\section{Saran}

Penulis melihat bahwa kenaikan harga BBM merupakan hal yang fundamental bagi masyarakat Indonesia. Pemerintah seharusnya bisa mencari solusi atas fenomena yang terjadi di masyarakat terutama dalam hal kenaikan BBM. Adapun saran-saran yang diberikan oleh penulis untuk sebagai masukan, sebagai berikut:

1) diperlukan tahap perencanaan, pelaksanaan dan evaluasi dalam program KIS, KIP dan KKS atas kompensasi kenaikan harga BBM, jadi jangan hanya pelaksanaannya saja yang dilakukan tapi evaluasi pun tetap harus dilakukan dengan baik. Apabila dalam perencanaan, pelaksanaan dan evaluasi tidak diterapkan atau gagal, maka nantinya akan menjadi program yang sia-sia dan hanya menghamburhamburkan uang negara. Lebih bagus lagi apabila kebijakan tersebut menyentuh impact (dampak) dan tidak stagnan di output atau outcome. Hal tersebut dapat dilakukan melalui website resmi dengan berupa informasi agar publik dapat mengaksesnya dengan mudah.

2) sebelum menaikan harga $B B M$ atau dicabutnya subsidi BBM, ada baiknya pemerintah memberantas mafia migas terlebih dahulu, baru kemudian di evaluasi kinerja PT. Pertamina.

3) prinsip-prinsip Good Governance harus segera diterapkan agar kekhawatiran masyarakat atas anggaran kompensasi kenaikan harga BBM seperti program KIS, KIP dan KKS dapat diselesaikan dengan baik. Terutama transparansi dan akuntabilitas yang harus bisa diakses oleh masyarakat dengan mudah, contohnya bisa dilakukan melalui website resmi dengan berupa informasi.

\section{DAFTAR PUSTAKA}

Adityowati, Putri. (2014). 4 Alasan Gerindra Tolak Jokowi Naikkan BBM, diakses pada tanggal $10 \quad$ Desember 2014, <http://www.tempo.co/read/news/2014/11/ 20/078623155/4-Alasan-Gerindra-TolakJokowi-Naikkan-BBM>.

Aspasia, Noor. (2014). Wapres: Kartu Sakti Punya Payung Hukum, diakses pada tanggal 10 Desember 2014, <http://www.cnnindonesia.com/nasional/2 0141107174803-20-10334/wapres-kartusakti-punya-payung-hukum/>.

Asril, Sabrina. (2014). Jokowi Tetapkan Harga Premium Rp8.500 dan Solar Rp7.500, diakses pada tanggal 10 Desember 2014, <http://nasional.kompas.com/read/2014/11 /17/21225431/Jokowi.Tetapkan.Harga.Pre mium.Rp.8.500.dan.Solar.Rp.7.500>. , (2014). Mensesneg: Anggaran Cetak KIP, KIS, dan KKS dari CSR BUMN, yang diakses pada tanggal 10 Desember 2014 , <http://nasional.kompas.com/read/2014/11 /05/21123161/Mensesneg.Anggaran.Cetak .KIP.KIS.dan.KKS.dari.CSR.BUMN>.

Firdaus, Randy Ferdi. (2014). BBM Naik, PKB Janji Kawal Jokowi Berantas Mafia Migas, diakses pada tanggal 10 Desember 2014, <http://www.merdeka.com/politik/bbmnaik-pkb-janji-kawal-jokowi-berantasmafia-migas.html>.

Firmansyah, Fery dan Bernadette Christina Munthe. (2014). Harga BBM Naik, Sofyan Djalil Malah Yakin Inflasi Menciut, 
diakses pada tanggal 10 Desember 2014, <http://www.tempo.co/read/news/2014/11/ 29/090625253/Harga-Minyak-DuniaMerosot-ke-Titik-Terendah>.

Gatra, Sandro. (2014). Demokrat Minta Presiden Jokowi Tidak Abaikan "Good Governance", diakses pada tanggal 10 Desember 2014 , <http://nasional.kompas.com/read/2014/11 /23/1616026/Demokrat.Minta.Presiden.Jok owi.Tidak.Abaikan.Good.Governance.>.

Globalindo, (2014). BI Siapkan Kendali Inflasi Dampak Kenaikan Harga BBM, diakses pada tanggal 10 Desember 2014, <http://www.globalindo.co/2014/11/13/bisiapkan-kendali-inflasi-dampak-kenaikanharga-bbm>.

(2014). Ini Strategi Jokowi Tekan

Inflasi Pasca Harga BBM Naik, diakses pada tanggal 10 Desember 2014, <http://www.globalindo.co/2014/11/24/ini -strategi-jokowi-tekan-inflasi-pasca-hargabbm-naik>.

Istianto, Bambang. (2011). Manajemen Pemerintahan Dalam Perspektif Pelayanan Publik, Jakarta: Penerbit Mitra Wacana Media.

JPNN, (2014). BBM Naik, Inflasi Sulit Dibendung, diakses pada tanggal 10 Desember 2014, <http://www.jpnn.com/read/2014/11/04/26 7718/BBM-Naik,-Inflasi-Sulit-Dibendung$>$.

Kamaludin, Arief. (2014). Dampak Kenaikan Harga BBM, Inflasi November 1,5 Persen, yang diakses pada tanggal 10 Desember 2014,

<http://katadata.co.id/berita/2014/12/01/da mpak-kenaikan-harga-bbm-inflasinovember-15-persen>.

Katadata, (2014). 10 Alasan Harga BBM Harus Naik, diakses pada tanggal 10 Desember 2014,

<http://katadata.co.id/infografik/2014/11/1 3/10-alasan-kenapa-harga-bbm-harusnaik>.

LIPI, (2005). Pusat Penelitian Politik Year Book 2005 Politik BBM, Jakarta: Yayasan Obor Indonesia.

Makmun, (2008). Studi Kemampuan Daerah Dalam Memberikan Subsidi Listrik, Dalam Jurnal Ekonomi dan Pembangunan, LIPI, Vol. XVI (1), Jakarta.

Manafe, Imanuel Nicolas. (2014). Jokowi: Kenaikan Harga BBM Untuk Alihkan Konsumtif ke Produktif, diakses pada tanggal $11 \quad$ Desember 2014, <http://www.tribunnews.com/nasional/201 4/11/19/jokowi-kenaikan-harga-bbmuntuk-alihkan-konsumtif-ke-produktif> .

Munawar, Dungtji, (2013). Memahami Pengertian dan Kebijakan Subsidi Dalam APBN, diakses pada tanggal 11 Desember 2014,

<http://www.bppk.kemenkeu.go.id/bdk/ci mahi/attachments/299_Memahami\%20Sub sidi.pdf $>$.

Nawangwulan, Maya, (2014). Harga BBM Naik, Ada Kartu Sehat, Pintar, Sejahtera, diakses pada tanggal 10 Desember 2014, <http://www.tempo.co/read/news/2014/10/ 31/087618427/Harga-BBM-Naik-AdaKartu-Sehat-Pintar-Sejahtera>.

Nurcholis, Hanif, (2005), Teori dan Praktik Pemerintahan dan Otonomi Daerah, Jakarta: Penerbit GRASINDO (Gramedia Widiasarana Indonesia),

Pertamina, Sejarah Pertamina, diakses pada tanggal $10 \quad$ Desember 2014, <http://www.pertamina.com/companyprofile/sejarah-pertamina/>.

_ Profil Perusahaan, diakses pada tanggal 10 Desember 2014, <http://www.pertamina.com/companyprofile/>.

Prabowo, Dani, (2014). Demokrat: Naikkan Harga BBM, Presiden Jokowi Terindikasi Langgar UU, diakses pada tanggal 10 Desember 2014, <http://nasional.kompas.com/read/2014/11 /18/1642142/Demokrat.Naikkan.Harga.BB M.Presiden.Jokowi.Terindikasi.Langgar.U U.>.

Punch, Keith F., (2000). Developing Effective Research Proposals, London: SAGE Publications.

Saputri, Dessy Suciati, (2014). Andrinof: Subsidi BBM Dialihkan ke Sektor Produktif, diakses pada tanggal 10 Desember 2014, <http://www.republika.co.id/berita/interna sional/global/14/11/17/nf6whe-andrinofsubsidi-bbm-dialihkan-ke-sektorproduktif $>$.

Suyanto, Bagong dan Sutinah ed., (2007). Metode Penelitian Sosial: Berbagai Alternatif Pendekatan, Jakarta: Kencana.

Virdhani, Marieska Harya, (2014), Kenaikan Harga BBM Bikin Gerah Mafia Migas, diakses pada tanggal 10 Desember 2014, <http://news.okezone.com/read/2014/11/2 0/337/1068122/kenaikan-harga-bbm-bikingerah-mafia-migas $>$.

Wicaksono, Kurniawan Agung, (2014). Harga BBM Naik, Sofyan Djalil Malah Yakin Inflasi Menciut, diakses pada tanggal 10 
Desember

2014

$<$ http://finansial.bisnis.com/read/20141201 19/276948/harga-bbm-naik-sofyan-djalilmalah-yakin-inflasi-menciut>. 